CONCISE REPORT

\title{
Combined intravenous methotrexate and cyclophosphamide for refractory childhood lupus nephritis
}

\author{
T J A Lehman, B S Edelheit, K B Onel
}

Ann Rheum Dis 2004;63:321-323. doi: 10.1136/ard.2003.008342

\begin{abstract}
Objective: To evaluate the efficacy and safety of combining monthly intravenous methotrexate (IV MTX) with monthly IV cyclophosphamide (CYTX; given on the same day) for the treatment of children who develop recurrent diffuse proliferative glomerulonephritis secondary to systemic lupus erythematosus during or after the standard 3 year course of IV CYTX.

Methods: Five children were treated with nine monthly doses of IV CYTX (750-1000 mg/m²/month) and IV MTX (50$300 \mathrm{mg} / \mathrm{m}^{2} /$ month) given on the same day. Their clinical and laboratory measurements were collected every other week throughout the nine months.

Results: All children improved dramatically. SLEDAI scores decreased from an average of 13.8 to 4.4 , mean (SD) serum creatinine level fell from $100(60)$ to $80(40) \mu \mathrm{mol} / \mathrm{l}$, and serum albumin rose from $28(11) \mathrm{g} / \mathrm{l}$ to 41 (6) $\mathrm{g} / \mathrm{l}$, while the mean (SD) C3 level increased from $0.5(0.1) \mathrm{g} / \mathrm{l}$ to 0.9 (0.4) $\mathrm{g} / \mathrm{l}$. Clinical improvement persisted after 4 years' follow up despite discontinuing MTX and CYTX after 9 months. The average daily dose of corticosteroids has been reduced from $27.6 \mathrm{mg} /$ day at the start of treatment to $12.5 \mathrm{mg} /$ day at follow up.

Conclusion: Combined IV MTX and IV CYTX treatment effectively controls recurrent or refractory lupus nephritis in children with significant disease activity after treatment with IV CYTX alone.
\end{abstract}

$\mathrm{T}$ he prognosis of children with systemic lupus erythematosus (SLE) has dramatically improved with the introduction of systematic intravenous cyclophosphamide (IV CYTX) treatment. ${ }^{1-3}$ In our experience, 6/42 children with biopsy proven diffuse proliferative glomerulonephritis (DPGN) have relapsed after a three year course of IV CYTX. ${ }^{12}$ These children experienced recurrent nephritis a mean (SD) of 24 (33) months (range 1-72) after completion of the standard 3 year IV CYTX regimen. One additional child developed DPGN while receiving IV CYTX every 3 months (after completing the initial course of monthly IV CYTX, which was started in her case to treat pulmonary haemorrhage).

Before the use of combined IV CYTX and IV methotrexate (MTX) two children with recurrent DPGN were treated with a second 3 year course of IV CYTX (total dosage $>34 \mathrm{~g} / \mathrm{m}^{2}$ ). Although the nephritis resolved in both cases, one child developed a renal papillary cell carcinoma and one remains amenorrhoeic 6 years after her last dose of CYTX. Our goal in using combined IV CYTX ( up to $1 \mathrm{~g} / \mathrm{m}^{2}$ ) and intravenous methotrexate (IV MTX) (up to $300 \mathrm{mg} / \mathrm{m}^{2}$ ) was to obtain more substantial immunosuppression in a shorter period with less likelihood of long term toxicity.

\section{METHODS}

All five treated children fulfilled the American College of Rheumatology criteria for a definite diagnosis of SLE. ${ }^{4}$ All had renal biopsy proven class IV DPGN. Initial treatment was $750-1000 \mathrm{mg} / \mathrm{m}^{2}$ of IV CYTX per dose given monthly for 7 months and then every 3 months for an additional 30 months ( 17 total doses over 36 months according to our published protocol) for all children. ${ }^{2}$ Four children had completed this regimen. The fifth child had received 11 doses of IV CYTX (monthly $\times 7$ doses and every 3 months $\times 4$ ) before developing DPGN.

All children were selected for combined IV CYTX and IV MTX treatment because of new (one case) or recurrent (four cases) worsening of haematuria and proteinuria with decreasing serum albumin, haemoglobin, and serum complement C3 and C4 levels, unresponsive to doubling the daily prednisone dosage. Before starting combined IV CYTX and IV MTX treatment all children were given folic acid $1 \mathrm{mg}$ daily, which was continued throughout. Informed consent was obtained in all cases.

Treatment was begun with IV CYTX at $750-1000 \mathrm{mg} / \mathrm{m}^{2}$ in $150 \mathrm{ml}$ D5W over 1 hour. Four hours later patients received IV MTX $50 \mathrm{mg} / \mathrm{m}^{2}$ in $100 \mathrm{ml}$ D5W over 4 hours. IV CYTX was continued at the maximum dose tolerated during the initial treatment with IV CYTX alone. The IV MTX dosage was increased to $100 \mathrm{mg} / \mathrm{m}^{2}$, then $150 \mathrm{mg} / \mathrm{m}^{2}$, and then $300 \mathrm{mg}$ / $\mathrm{m}^{2}$ as tolerated by each child. If the absolute neutrophil count fell below $0.5 \times 10^{9}$ neutrophils/1 10-14 days after treatment, the next dose of IV MTX was reduced by $25 \%$ and the lower dose was maintained for the remainder of the study. No child received more than $300 \mathrm{mg} / \mathrm{m}^{2}$ of IV MTX. The IV CYTX dose was held constant throughout.

Treatment with combined IV CYTX and IV MTX was continued at monthly intervals for 9 months. All children were observed in the hospital for at least 12 hours before IV CYTX and IV MTX for evidence of fever, irregular vital signs, or other findings suggesting infection. Samples were obtained for complete blood count (CBC), erythrocyte sedimentation rate (ESR), $\mathrm{Na}, \mathrm{K}, \mathrm{Cl}, \mathrm{CO}_{2}$, blood urea nitrogen (BUN), aspartate aminotransferase (AST), alanine aminotransferase (ALT), creatinine (Cr), antinuclear antibodies (ANA), C3, and C4 at the time of admission. Twenty four hour urine for protein, $\mathrm{Cr}$, and $\mathrm{CrCl}$ was also obtained. All children were treated in hospital and received intravenous hydration $\left(2 \mathrm{l} / \mathrm{m}^{2} / 24 \mathrm{~h}\right.$ D5 $\left.0.5 \mathrm{NS}\right)$ for 12 hours before and 24 hours after IV CYTX, and intravenous MESNA for 12 hours after the IV CYTX. ${ }^{2}$ Fourteen days after combined

\footnotetext{
Abbreviations: ALT, alanine aminotransferase; ANA, antinuclear antibodies; AST, aspartate aminotransferase; BUN, blood urea nitrogen; CBC, complete blood count; $\mathrm{Cr}$, creatinine; CYTX, cyclophosphamide; DPGN, diffuse proliferative glomerulonephritis; ESR, erythrocyte sedimentation rate; IV, intravenous; MTX, methotrexate; SLE, systemic lupus erythematosus; SLEDAI, SLE disease activity index
} 


\begin{tabular}{|c|c|c|c|}
\hline Variable & $\begin{array}{l}\text { Before } \\
\text { treatment }\end{array}$ & $\begin{array}{l}\text { After } \\
\text { treatment }\end{array}$ & $\begin{array}{l}\text { Paired } t \text { test } \\
\text { ( } p \text { value) }\end{array}$ \\
\hline $\begin{array}{l}\text { SLEDAl } \\
\text { Serum albumin }(\mathrm{g} / \mathrm{l}) \\
\text { Total protein }(\mathrm{g} / \mathrm{l}) \\
\text { C3 }(\mathrm{g} / \mathrm{l}) \\
\text { Serum creatinine }(\mu \mathrm{mol} / \mathrm{l}) \\
\text { Prednisone }(\mathrm{mg} / \text { day) }\end{array}$ & $\begin{array}{l}13.8(7.0) \\
28(11) \\
52(12) \\
0.5(0.1) \\
100(60) \\
27.6(7.8)\end{array}$ & $\begin{array}{l}4.4(3.6) \\
41(6) \\
67(7) \\
0.9(0.4) \\
80(40) \\
12.5(5.0)\end{array}$ & $\begin{array}{l}<0.01 \\
<0.025 \\
<0.025 \\
<0.025 \\
\text { NS } \\
<0.01\end{array}$ \\
\hline
\end{tabular}

IV CYTX and IV MTX all children were evaluated in the outpatient department and the determination of CBC, ESR, $\mathrm{Na}, \mathrm{K}, \mathrm{Cl}, \mathrm{CO}_{2}, \mathrm{BUN}, \mathrm{AST}, \mathrm{ALT}, \mathrm{Cr}, \mathrm{ANA}, \mathrm{C} 3$, and $\mathrm{C} 4$ repeated.

Because of the small sample size statistical analysis was performed using one tailed $t$ tests. This was consistent with our hypothesis that IV CYTX and IV MTX treatment would be associated with improvement.

\section{RESULTS}

Table 1 shows that all children improved with combined IV CYTX and IV MTX treatment. There were statistically significant reductions in the mean SLE disease activity index (SLEDAI) score (fig l) and mean daily prednisone dose (fig 2) and statistically significant increases in mean serum albumin, total protein, and serum C3 level. The mean serum creatinine level remained in the normal range.

Side effects of combined IV CYTX and IV MTX treatment included leucopenia in $4 / 5$ and mild mucositis $2 / 5$ children. The leucopenia occurred at an MTX dose of $150 \mathrm{mg} / \mathrm{m}^{2}$ in two children and at $300 \mathrm{mg} / \mathrm{m}^{2}$ in two others. In all cases the leucopenia resolved when the dose was reduced. One child required IV acyclovir because of recurring Herpes zoster infection. Two children required admission for observation because of fever and neutropenia between treatments with IV CYTX and IV MTX but were without infection.

All children completed nine treatments with combined IV CYTX and IV MTX. All remain stable a mean of 4 years (range 1-10) after treatment, without recurrent active nephritis or evidence of IV CYTX and IV MTX related toxicity.

\section{DISCUSSION}

DPGN secondary to SLE is a severe life threatening condition. ${ }^{5-7}$ Over the past 20 years the prognosis for children with DPGN has dramatically improved. This is due in part to the advent of improved paediatric intensive care units, improved antibiotic regimens, and the systematic use of IV CYTX. ${ }^{189}$ Systematic use of a 3 year course of IV CYTX has been very successful for most children with DPGN. ${ }^{2}$ However, in our experience recurrent DPGN related disease activity has occurred in $6 / 42$ children ( $14 \%$ ) who completed three years of IV CYTX.

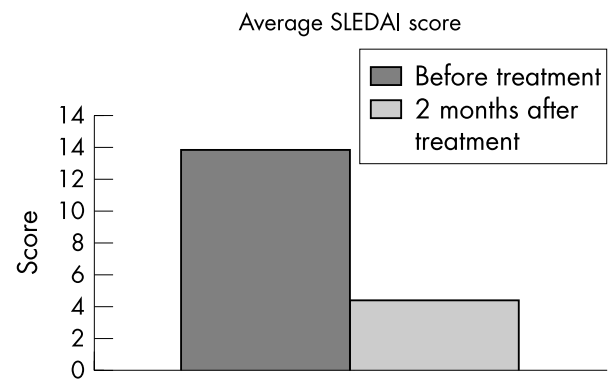

Figure 1 Average SLEDAI score before and after treatment.

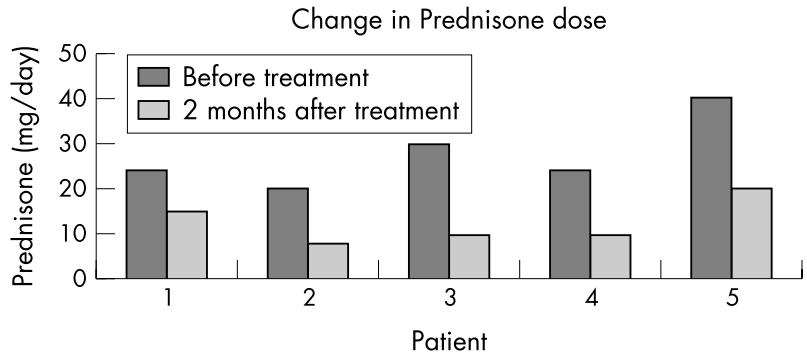

Figure 2 Change in daily prednisone dose before and after treatment.

Before this study there were no reports of consistently successful treatment for children with recurrent disease after completion of systematic IV CYTX treatment. Our experience showed that repeated treatment with a further 36 month course of IV CYTX alone carried an unacceptable risk of long term toxicity. We chose to combine IV CYTX and IV MTX after the oncologists' precept that combining two drugs with different dose limiting toxicities and mechanisms of action should have a synergistic effect without a corresponding increase in treatment related toxicity. ${ }^{10}$ Our findings suggest this is true in SLE as well.

Autologous bone marrow transplantation, ${ }^{11}$ and high dose IV CYTX ablation, ${ }^{13}{ }^{14}$ have been suggested for patients with severe SLE. Both have significant morbidity and mortality. The children in our study experienced long term remission without toxicity comparable to these treatments.

All the children in this group were expected to progress to renal failure and dialysis without aggressive intervention. After combined IV CYTX and IV MTX treatment four improved dramatically and the fifth stabilised. Our results suggest that more careful consideration should be given to the use of combined agent regimens in the treatment of children with DPGN. Such regimens may result in greater efficacy and lower toxicity.

\section{Authors' affiliations}

T J A Lehman, K B Onel, B S Edelheit, Division of Paediatric Rheumatology, Hospital for Special Surgery, and Department of Paediatrics, Sanford Weill Medical College of Cornell University, USA

Correspondence to: $\operatorname{Dr} \mathrm{T} J \mathrm{~A}$ Lehman MD, Hospital for Special Surgery, 535 E 70th St, New York, NY 10021, USA; goldscout@aol.com

Accepted 20 May 2003

\section{REFERENCES}

1 Lehman TJA, Sherry D, Wagner L, McCurdy DK, Emery H, Magilavy D, et al. Intermittent intravenous cyclophosphamide therapy for lupus nephritis. J Pediatr 1989:1 14:1055-60.

2 Lehman TJA, Onel KB. Intermittent intravenous cyclophosphamide arrests progression of the renal chronicity index in childhood systemic lupus erythematosus. J Pediatr 2000;136:243-7.

3 McCurdy D, Lehman TJA, Bernstein B, Hanson V, King KK, Naodra R, et al. Lupus nephritis: prognostic factors in children. Pediatrics 1992;89:240-6.

4 Tan EM, Cohen AS, Fries JF, Masi AT, McShane DJ, Rothfield NF, et al. The 1982 Revised criteria for the classification of systemic lupus erythematosus. Arthritis Rheum 1982;25:1271-7.

5 Barron KS, Donald MD, Person MD, Brewer EJ Jr, Beale MG, Robson AM Pulse methylprednisolone therapy in diffuse proliferative lupus nephritis. J Pediatr 1982;101:137-41.

6 Schaller J. Lupus in Childhood. Clin Rheum Dis 1982;8:219-28.

7 Ansell B. Perspectives in pediatric systemic lupus erythematosus. J Rheumatol 1987; 14:177-9.

8 Lehman TJA. Long-term outcome of systemic lupus erythematosus in childhood: what is the prognosis. Rheum Dis Clin North Am 1991;17:921-30.

9 Klippel JH, Austin HA, Balow JE, leRiche GH, Steinberg AD, Plotz PH, et al. Studies of immunosuppressive drugs in the treatment of lupus nephritis. Rheum Dis Clin North Am 1987; 13:47-56.

10 Yarboro JW. Scientific basis of chemotherapy. In: Perry MC, ed. The chemotherapy sourcebook. Baltimore: Williams and Wilkins, 1992:8-9. 
11 Gur-Lavi M Long-term remission with allogenic bone marrow transplantation in systemic lupus erythematosus. Arthritis Rheum 1999;42:1777.

12 Wulffraat NM, Sanders EAM, Kamphuis SSM, Rijkers GT, Kuis W, Lilien M Gur-Lavi M. Prolonged remission without treatment after autologous stem cell transplantation for refractory childhood systemic lupus erythematosus. Arthritis Rheum 2001:44:728-34.
13 Takada K, Illei GG Boumpas DT. Cyclophosphamide for the treatment of systemic lupus erythematosus. Lupus 2001;10:154-61.

14 Petri M, Jones R, Brodsky R. High dose immunoablative cyclophosphamide (HDIC) in SLE: complete responders and durability of response in the open label trial [abstract]. Arthritis Rheumatism $2001 ; 44$ (suppl):S387

\section{Clinical Evidence-Call for contributors}

Clinical Evidence is a regularly updated evidence based journal available worldwide both as a paper version and on the internet. Clinical Evidence needs to recruit a number of new contributors. Contributors are health care professionals or epidemiologists with experience in evidence based medicine and the ability to write in a concise and structured way.

\section{Currently, we are interested in finding contributors with an interest in} the following clinical areas:

Altitude sickness; Autism; Basal cell carcinoma; Breast feeding; Carbon monoxide poisoning; Cervical cancer; Cystic fibrosis; Ectopic pregnancy; Grief/bereavement; Halitosis; Hodgkins disease; Infectious mononucleosis (glandular fever); Kidney stones; Malignant melanoma (metastatic); Mesothelioma; Myeloma; Ovarian cyst; Pancreatitis (acute); Pancreatitis (chronic); Polymyalgia rheumatica; Post-partum haemorrhage; Pulmonary embolism; Recurrent miscarriage; Repetitive strain injury; Scoliosis; Seasonal affective disorder; Squint; Systemic lupus erythematosus; Testicular cancer; Varicocele; Viral meningitis; Vitiligo

However, we are always looking for others, so do not let this list discourage you.

Being a contributor involves:

- Appraising the results of literature searches (performed by our Information Specialists) to identify high quality evidence for inclusion in the journal.

- Writing to a highly structured template (about 2000-3000 words), using evidence from selected studies, within 6-8 weeks of receiving the literature search results.

- Working with Clinical Evidence Editors to ensure that the text meets rigorous epidemiological and style standards.

- Updating the text every eight months to incorporate new evidence.

- Expanding the topic to include new questions once every 12-18 months.

If you would like to become a contributor for Clinical Evidence or require more information about what this involves please send your contact details and a copy of your CV, clearly stating the clinical area you are interested in, to Claire Folkes (cfolkes@bmigroup.com).

\section{Call for peer reviewers}

Clinical Evidence also needs to recruit a number of new peer reviewers specifically with an interest in the clinical areas stated above, and also others related to general practice. Peer reviewers are health care professionals or epidemiologists with experience in evidence based medicine. As a peer reviewer you would be asked for your views on the clinical relevance, validity, and accessibility of specific topics within the journal, and their usefulness to the intended audience (international generalists and health care professionals, possibly with limited statistical knowledge). Topics are usually 2000-3000 words in length and we would ask you to review between 2-5 topics per year. The peer review process takes place throughout the year, and our turnaround time for each review is ideally 10-14 days.

If you are interested in becoming a peer reviewer for Clinical Evidence, please complete the peer review questionnaire at www.clinicalevidence.com or contact Claire Folkes(cfolkes@bmigroup.com). 